Article

\title{
Surface Characterization and Physiochemical Evaluation of P(3HB-co-4HB)-Collagen Peptide Scaffolds with Silver Sulfadiazine as Antimicrobial Agent for Potential Infection-Resistance Biomaterial
}

\author{
Sevakumaran Vigneswari ${ }^{1}{ }^{(1)}$, Tana Poorani Gurusamy ${ }^{2}$, Wan M. Khairul ${ }^{1}$, Abdul Khalil H.P.S. ${ }^{3}{ }^{\mathbb{D}}$, \\ Seeram Ramakrishna ${ }^{4}$ (D) and Al-Ashraf Abdullah Amirul $2,5,6, *$ (D) \\ 1 Faculty of Science and Marine Environment, Universiti Malaysia Terengganu, \\ Kuala Terengganu 21030, Terengganu, Malaysia; vicky@umt.edu.my (S.V.); \\ wmkhairul@umt.edu.my (W.M.K.) \\ 2 School of Biological Sciences, Universiti Sains Malaysia, Gelugor 11800, Penang, Malaysia; \\ purani_guru@yahoo.com \\ 3 School of Industrial Technology, Universiti Sains Malaysia, Gelugor 11800, Penang, Malaysia; \\ akhalilhps@gmail.com \\ 4 Center for Nanofibers and Nanotechnology, Department of Mechanical Engineering, National University \\ of Singapore, Singapore 117581, Singapore; seeram@nus.edu.sg \\ check for \\ updates \\ Citation: Vigneswari, S.; Gurusamy, \\ 5 Centre for Chemical Biology, Universiti Sains Malaysia, Bayan Lepas 11900, Penang, Malaysia \\ 6 Malaysian Institute of Pharmaceuticals and Nutraceuticals, NIBM, Gelugor 11700, Penang, Malaysia \\ * Correspondence: amirul@usm.my
} T.P.; Khairul, W.M.; H.P.S., A.K.; Ramakrishna, S.; Amirul, A.-A.A Surface Characterization and Physiochemical Evaluation of P(3HB-co-4HB)-Collagen Peptide Scaffolds with Silver Sulfadiazine as Antimicrobial Agent for Potential Infection-Resistance Biomaterial. Polymers 2021, 13, 2454. https:// doi.org/10.3390/polym13152454

Academic Editors: Ariana Hudita and Bianca Gălăţeanu

Received: 4 July 2021

Accepted: 20 July 2021

Published: 26 July 2021

Publisher's Note: MDPI stays neutral with regard to jurisdictional claims in published maps and institutional affiliations.

Copyright: (c) 2021 by the authors Licensee MDPI, Basel, Switzerland. This article is an open access article distributed under the terms and conditions of the Creative Commons Attribution (CC BY) license (https:// creativecommons.org/licenses/by/ $4.0 /)$
Abstract: Poly(3-hydroxybutyrate-co-4-hydroxybutyrate) [P(3HB-co-4HB)] is a bacterial derived biopolymer widely known for its unique physical and mechanical properties to be used in biomedical application. In this study, antimicrobial agent silver sulfadiazine (SSD) coat/collagen peptide coat$\mathrm{P}(3 \mathrm{HB}-\mathrm{co}-4 \mathrm{HB})$ (SCCC) and SSD blend/collagen peptide coat- $\mathrm{P}(3 \mathrm{HB}-\mathrm{co}-4 \mathrm{HB})$ scaffolds (SBCC) were fabricated using a green salt leaching technique combined with freeze-drying. This was then followed by the incorporation of collagen peptides at various concentrations $(2.5-12.5 \mathrm{wt} . \%)$ to $\mathrm{P}(3 \mathrm{HB}-\mathrm{co}-4 \mathrm{HB})$ using collagen-coating. As a result, two types of $\mathrm{P}(3 \mathrm{HB}-\mathrm{co}-4 \mathrm{HB})$ scaffolds were fabricated, including SCCC and SBCC scaffolds. The increasing concentrations of collagen peptides from $2.5 \mathrm{wt}$. $\%$ to $12.5 \mathrm{wt}$ \% exhibited a decline in their porosity. The wettability and hydrophilicity increased as the concentration of collagen peptides in the scaffolds increased. In terms of the cytotoxic results, MTS assay demonstrated the L929 fibroblast scaffolds adhered well to the fabricated scaffolds. The $10 \mathrm{wt} . \%$ collagen peptides coated SCCC and SBCC scaffolds displayed highest cell proliferation rate. The antimicrobial analysis of the fabricated scaffolds exhibited $100 \%$ inhibition towards various pathogenic microorganisms. However, the SCCC scaffold exhibited 100\% inhibition between 12 and $24 \mathrm{~h}$, but the SBCC scaffolds with SSD impregnated in the scaffold had controlled release of the antimicrobial agent. Thus, this study will elucidate the surface interface-cell interactions of the SSD-P(3HB-co-4HB)-collagen peptide scaffolds and controlled release of SSD, antimicrobial agent.

Keywords: $\mathrm{P}(3 \mathrm{HB}-\mathrm{co}-4 \mathrm{HB})$; silver sulfadiazine; collagen peptide; infection-resistance scaffolds

\section{Introduction}

Biomaterial scaffolds are materials which have been engineered to interact with our biological system in providing three-dimensional structure and mimicking an extracellular matrix (ECM). Therefore, it is crucial to design biologically active scaffolds with well interconnected configuration and surface chemistry to enhance the cellular interactions on the scaffold interface [1,2]. The scaffold interface would enhance and facilitate the cell infiltration, proliferation and differentiation of cell lines, and eventually contribute to the tissue regeneration. 
Polyhydroxyalkonates (PHAs) are insoluble granules accumulated in cell cytoplasm as carbon and energy storage compounds under stress conditions [3-5]. PHAs are a biodegradable thermoplastic which exhibit similar thermo-mechanical properties to synthetic polymers [6]. Among the variety of PHAs, copolymer $\mathrm{P}(3 \mathrm{HB}-\mathrm{co}-4 \mathrm{HB})$ is widely used in biomedical applications due to the non-toxic biodegradation products, wide range of physical and mechanical properties, non-carcinogenic effects and biocompatibility [7]. It possesses exceptional properties for medical and pharmaceutical fields [8,9]. Moreover, $\mathrm{P}(3 \mathrm{HB}-\mathrm{co}-4 \mathrm{HB})$ has Food and Drug Administration (FDA) clearance for clinical usages among all the other PHAs available [3]. The P(3HB-co-4HB) was biosynthesized by bacterium Cupriavidus necator (formally Ralstonia eutropha) from structurally related sources such as 4-hydroxybutyric acid (4HBA), 4-chlorobutyric and $\gamma$-butyrolactone [7].

However, $\mathrm{P}\left(3 \mathrm{HB}-\mathrm{co}^{-4 \mathrm{HB})}\right.$ lacks active functional sites for cell attachment which limits the applications for regenerative medicine. Many studies have been carried out in this direction to overcome this limitation. Therefore, surface modification is carried out by incorporating natural polymers, such as collagen, gelatin, pullulan and chitosan, in enhancing the hydrophilicity of the scaffolds [10]. Nevertheless, the desirability and wide applicability of collagen is often attributed to its abundance in the human body as the key structural fibrous protein of the ECM [11]. Hence, collagen peptide was used as the biomolecules to enhance the hydrophilicity of the scaffolds fabricated in our study. Collagen peptide is a biomolecule which not only has the ability to improve the hydrophilicity of the scaffold but has the natural ability to interact with host cells [12,13].

Biomaterial scaffold-affiliated microbial infections are an emerging threat in clinical practices, which cause serious infection and impact healing. Therefore, designing scaffolds with antimicrobial efficacy have extensively gained priority in resolving biomaterialassociated infections [14]. Silver sulfadiazine (SSD) is an antibacterial agent that exhibits broad-spectrum antibacterial activity against Gram-positive and Gram-negative bacteria, as well as fungi, even at very low concentrations [15-17]. SSD is a much preferred antibacterial agent of choice due to the ability of SSD to reduce early infections at low concentration. However, currently available formulations of antimicrobial agents lack the ability to control the release of antimicrobial properties $[18,19]$. There are many scaffolds developed with antimicrobial properties and Table 1 lists common examples of antimicrobial biopolymer incorporated with SSD.

Table 1. List of common examples of various antimicrobial scaffolds incorporated with SSD.

\begin{tabular}{|c|c|c|c|}
\hline Biopolymer/Materials & Fabrication of Scaffolds & Applications & References \\
\hline Collagen/SSD & Facile blending & Wound dressings & [19] \\
\hline Collagen/SSD & Electrospinning & Wound healing applications & [15] \\
\hline Collagen/SSD & $\begin{array}{l}\text { Blending with SSD-loaded } \\
\text { alginate microspheres }\end{array}$ & $\begin{array}{l}\text { Conventional burn dressings in } \\
\text { second-degree burns }\end{array}$ & [16] \\
\hline Polycaprolactone (PCL)/SSD & Electrospinning & Antibacterial scaffold & [20] \\
\hline $\begin{array}{l}\mathrm{P}(3 \mathrm{HB}-\mathrm{co}-4 \mathrm{HB}) / \text { collagen } \\
\text { peptide/SSD }\end{array}$ & Aminolysis & Potential wound healing & [9] \\
\hline $\begin{array}{l}\text { Polycaprolactone (PCL) and } \\
\text { Polyvinyl alcohol (PVA)/SSD }\end{array}$ & Electrospinning & Antimicrobial wound dressing & [21] \\
\hline Poly(lactic acid) (PLA)/SSD & $\begin{array}{c}\text { Electrospinning, } \\
\text { structural reconstruction }\end{array}$ & Antimicrobial wound dressing & [22] \\
\hline
\end{tabular}

Following the aforementioned background, in the present work, the surface architecture of $\mathrm{P}(3 \mathrm{HB}-\mathrm{co}-4 \mathrm{HB})$ was enhanced by incorporating collagen peptides and silver sulfadiazine (SSD) as the antimicrobial mechanism agent. Two different scaffolds, namely SSD coat/collagen peptide coat-P(3HB- $-0-4 \mathrm{HB})$ [SSCC] and SSD blend/collagen peptides coat- $\mathrm{P}(3 \mathrm{HB}-\mathrm{co}-4 \mathrm{HB})[\mathrm{SBCC}]$ scaffold, were fabricated by the combination of salt leaching 
and freeze-drying techniques which are low cost and apply green technology to fabricate the scaffolds. The study provides evidence for increased hydrophilicity due to the incorporation of collagen peptide. This elucidates surface interface-cell interactions of the modified $\mathrm{P}(3 \mathrm{HB}-\mathrm{co}-4 \mathrm{HB})$ scaffolds and release mechanism of the antimicrobial agent from the scaffolds, thus driving the research effort forward for emerging infection-resisting biomaterials in tissue engineering and regenerative medicine in the future.

\section{Materials and Methods}

\subsection{Biosynthesis of $\mathrm{P}(3 \mathrm{HB}-\mathrm{co}-95 \mathrm{~mol} \% 4 \mathrm{HB})$ Copolymer}

The bacteria strains used in this study were Cupriavidus malaysiensis USMAA1020 transformant harbouring additional PHA synthase gene from Cupriavidus malaysiensis USMAA2-4 to produce $\mathrm{P}(3 \mathrm{HB}-\mathrm{co}-95 \mathrm{~mol} \% 4 \mathrm{HB})$ copolymer. The biosynthesis was carried out as previously described [23]. A preculture of $5 \%(v / v)$ of the working volume was transferred into $20 \mathrm{~L}$ fermenter (Biostat ${ }^{\circledR} \mathrm{C}$ plus, Sartorius Stedim, German) containing mineral salts medium (MSM) with carbon precursors (1,4-butanediol and 1,6-hexanediol in the 1:5 ratio). The fermentation was carried out at $30^{\circ} \mathrm{C}$ with an agitation speed of $200 \mathrm{rpm}$, the aeration rate of $1 \mathrm{vvm}$ and controlled $\mathrm{pH}$ of 7 for $108 \mathrm{~h}$. Sampling was done at intervals of every $12 \mathrm{~h}$. The composition of PHA produced was determined by gas chromatography (GC) using Shimadzu Gas Chromatography GC-2014 according to methods previously described [24]. Endotoxin removal was carried out on extracted P(3HB-co-95 mol\% 4HB) copolymer as previously described. The extracted polymer was characterized based on the molecular weight using Shimadzu GPC-2014 and tensile test using tensile testing machine (GoTech Al-3000, Shimadzu, Japan) [24].

\subsection{Surface Functionalization of SSD/Collagen Peptide-P(3HB-co-4HB) Scaffolds}

Surface functionalization of $\mathrm{P}(3 \mathrm{HB}-\mathrm{co}-4 \mathrm{HB})$ was carried out by salt leaching and solvent casting technique followed by freeze-drying method. Briefly, $\mathrm{P}(3 \mathrm{HB}-\mathrm{co}-4 \mathrm{HB})$ copolymer was dissolved in chloroform $(5.5 \% \mathrm{w} / \mathrm{v})$ and sodium bicarbonate $\left(\mathrm{NaHCO}_{3}\right)$ particles sieved with known mesh sizes $(200 \mu \mathrm{m})$ were added as porogen with mass ratio of salt:polymer at 6:1. The resulting polymer matrix was washed with deionized water to leach out the porogens. The scaffolds were freeze-dried for $24 \mathrm{~h}$ and later vacuum-dried for $48 \mathrm{~h}$ (BINDER GmbH, Tuttlingen, Germany) to remove any remaining solvent.

There were two types of scaffolds prepared using the various functionalization combination methods by incorporating different concentration of collagen peptide ( $2.5 \mathrm{wt} . \%$, $5 \mathrm{wt} . \%, 7.5 \mathrm{wt} . \%, 10 \mathrm{wt} . \%, 12.5 \mathrm{wt} . \%$ ) and $0.04 \%$ (w/v) of SSD. Collagen peptide powder from Tilapia fish skin with high purity (95\%) and molecular weight of less than $3000 \mathrm{Da}$ was used (Hainan Zhongxin Chemical Co. Ltd., Haikou, China).

The SSD coat/collagen peptide coat-P(3HB-co-4HB) scaffold (SCCC) was prepared by coating different concentration of collagen peptide in the silver (I) sulfadiazine (Sigma Aldrich) dispersed in hydrochloric acid solution (1.0 mM, pH 3.0).

The preparation of SSD blend/collagen peptide coat-P(3HB-co-4HB) scaffold (SBCC) was prepared with SSD added into the dissolved $\mathrm{P}(3 \mathrm{HB}-\mathrm{co}-4 \mathrm{HB})$ with $\mathrm{NaHCO}_{3}$ porogen and then solvent cast, as mentioned above.

Cross-linking was carried out using GA vapor-phase technique where the scaffolds were placed in an airtight desiccator containing $25 \%$ aqueous GA solution heated to $100{ }^{\circ} \mathrm{C}$. Subsequently, the samples were washed for $24 \mathrm{~h}$ to remove GA, and then dried in vacuum for $24 \mathrm{~h}[8,25]$. The scaffolds will be known as SCCC and SBCC from here on.

\subsection{Characterization of Scaffolds}

The functional group present in the scaffolds fabricated were determined and analyzed using FTIR-ATR spectrophotometer (Model RX1, PerkinElmer, Buckinghamshire, UK). The spectra of the samples were obtained in the range of wave number between $650 \mathrm{~cm}^{-1}$ and $4000 \mathrm{~cm}^{-1}$. The spectrum of the FTIR was recorded in transmittance mode as function of wave number and the results were computed after 4 automated scans [24]. The surface 
morphology of the scaffolds coated with gold were mounted on aluminium stump and was observed using scanning electron microscopy (SEM) (Leo Supra 50 VP Field Mission SEM, Carl-Ziess SMT, Oberkochen, Germany). The scaffolds were cut into $1 \mathrm{~cm} \times 1 \mathrm{~cm}$. The dry weight before immersion $\left(m_{0}\right)$ was used as the initial weight of the scaffolds. The scaffolds were immersed in distilled water for $24 \mathrm{~h}$. In order to obtain the wet weights $\left(m_{f}\right)$, the immersed scaffolds were removed from the solution, gently wiped with absorbent paper and air-died for $15 \mathrm{~s}$ before weighing. Water uptake was calculated using the formula below:

$$
\text { Water uptake }=\left(m_{0}-m_{f}\right) / m_{0} \times 100 \%
$$

The contact angle of the fabricated scaffolds was conducted by using sessile drop method (KSV CM200 Contact Angle) to determine their wettability properties. The scaffolds were cut into $1 \mathrm{~cm} \times 1 \mathrm{~cm}$ pieces. The scaffolds were placed on the instrument and the droplet of water was then deposited on the polymer surface by a specialized microsyringe. The water droplet was observed from the computer screen and the contact angle was calculated. The porosity of the scaffolds was calculated using Image Analyser Software (Olympus Co. Ltd., Tokyo, Japan). The values of 100 different spots were analyzed and averaged [8].

\subsection{Antimicrobial Activity}

Four bacterial strains, which include Bacillus licheniformis, Staphylococcus aureus ATCC 12600, Escherichia coli ATCC 11303 and Pseudomonas aeruginosa ATCC 17588, were used. Briefly, the tested bacterial suspensions $\left(1.5 \times 10^{6} \mathrm{CFU} / \mathrm{mL}\right)$ were transferred in sterilized nutrient broth. Then, $20 \mu \mathrm{L}$ of the bacteria suspension $\left(7.5 \times 10^{5} \mathrm{CFU} / \mathrm{mL}\right)$ was added to each antimicrobial coated porous scaffold. The incubation is done under suitable conditions for varied time intervals $(0,6,12$ and $24 \mathrm{~h})$. In every $6 \mathrm{~h}$ interval, the scaffold with bacteria adhesion was dissolved in $10 \mathrm{~mL}$ of distilled water and vortexed. After that, $100 \mu \mathrm{L}$ of the bacterial suspension was spread on nutrient agar to observe the colonization of bacteria. The percentage of dead cells is calculated relatively to the growth control by determining the number of living cells $(\mathrm{CFU} / \mathrm{mL})$ of each scaffold using the agar plate count method. The percentages of inhibition were calculated using following Equation:

$$
C \%=(C o-C e) / C o \times 100 \%
$$

where $C \%$ is percentage of inhibition, $C e$ is $C F U$ after incubation period and $C o$ is initial CFU before incubation period.

\subsection{Biocompatibility and Cell Proliferation Evaluation}

Mouse fibroblast cell culture (L929, ATCC) was cultured in cell culture flasks containing Modified Eagle Medium (MEM) supplemented with $2 \mathrm{mM} \mathrm{L-glutamine,} 1.5 \mathrm{~g} / \mathrm{L}$ sodium bicarbonate, $1 \mathrm{mM}$ of sodium pyruvate, $1000 \mathrm{U} / \mathrm{mL}$ penicillin-streptomycin and $10 \%(v / v)$ of bovine calf serum, which were incubated at $37^{\circ} \mathrm{C}$ in $5 \%(v / v) \mathrm{CO}_{2}$ for $2-3$ days. The various scaffolds fabricated and its positive control ( $\mathrm{P}(3 \mathrm{HB}-\mathrm{co}-4 \mathrm{HB})$ without collagen were cut in size ( $6 \mathrm{~mm}$ in diameter) fitting the 96-well flat bottom culture plate and sterilized under UV cross-linker (Spectrolinker ${ }^{\mathrm{TM}}$, XL-1000 UV Cross-linker, Westbury, NY, USA) at $1200 \mu \mathrm{J} / \mathrm{cm}^{2}$ for $30 \mathrm{~min}[8,9]$. The scaffolds were then placed in the 96-well flat bottom culture plate. Suspension of the mouse fibroblast cell lines (L929) [2.5 $\times 10^{4}$ cells $\left./ \mathrm{mL}\right]$ were directly cultivated onto the scaffolds and film. The seeded scaffolds and film were incubated in a $5 \%(v / v) \mathrm{CO}_{2}$ incubator at $37^{\circ} \mathrm{C}$ for $96 \mathrm{~h}$. The cells viability and proliferation were assayed with MTS[3-(4,5-dimethylthiazol-2-yl)-5-(3-carboxymethoxyphenyl)-2-(4sulfophenyl)-2H-tetrazolium/PMS (phenazinmethosulfate). MTS and PMS solution were used to evaluate the biocompatibility of the fabricated of scaffolds. Standard curve was plot based on the cell density from the range of $1 \times 10^{3}$ to $5 \times 10^{5}$ cells $/ \mathrm{mL}$. The media was used as the positive control and scaffolds without any incorporation of collagen peptide 
were used as negative control. The absorbance values were plotted against the counted cell numbers, and thus a standard curve was established [9].

\subsection{Statistical Analysis}

The qualitative results were presented as means and standard deviation (s.d). The qualitative data were analyzed using ANOVA and Tukey's HSD test with SPSS 20.0 software. All $p$ values $<0.05$ were considered significant.

\section{Results and Discussion}

\subsection{Biosynthesis of $P(3 H B-c o-4 H B)$ via Batch Fermentation}

The biosynthesis of $\mathrm{P}(3 \mathrm{HB}-\mathrm{co}-4 \mathrm{HB})$ copolymer was carried out using Cupriavidus malaysianesis USMAA1020 transformant, which possessed an excess copy of the phaC gene. This cultivation regulated $4 \mathrm{HB}$ molar fraction to achieve $95 \mathrm{~mol} \%$ of $\mathrm{P}(3 \mathrm{HB}-\mathrm{co}-$ $4 \mathrm{HB}$ ) with PHA content of $78 \mathrm{wt} . \%$ and its concentration at $17.3 \mathrm{~g} / \mathrm{L}$ in $20 \mathrm{~L}$ bioreactor, the mixed substrates of 1,6-hexanediol and 1,4-butanediol at 1:5 ratio. The high $4 \mathrm{HB}$ monomers are favored for implantable medical products. This was in agreement with the previous study [23], the 1,6-hexanediol and 1,4-butanediol were utilized as carbon sources as 4-hydroxybutyryl-CoA was initially formed and converted to 4-hydroxybutyrate. The copolymer was recovered by the chloroform extraction method and subjected to physical properties. Based on the results obtained, as summarized Table 2, the average molecular weight (MW) of the polymer was $585 \mathrm{kDa}$ while the polydispersity index was in the range 3.2. Besides, the tensile strength of the polymer was recorded at about $23 \mathrm{MPa}$ with the elongation at break around $611 \%$.

Table 2. Physical and mechanical properties of $\mathrm{P}(3 \mathrm{HB}-\mathrm{co}-4 \mathrm{HB})$.

\begin{tabular}{ccccccc}
\hline \multirow{2}{*}{ Copolymer } & Tensile Strength & Elongation at Break & Young Modulus & $\mathbf{M}_{\mathbf{w}}$ & $\mathbf{M}_{\mathbf{n}}$ & $\mathbf{P D I}^{\mathbf{b}}$ \\
\cline { 2 - 5 } & $\mathbf{( M P a}^{\mathbf{a}}$ & $\mathbf{( \% )}^{\mathbf{a}}$ & $\mathbf{( M p a )}^{\mathbf{a}}$ & $\mathbf{( k D a )}^{\mathbf{b}}$ & $\mathbf{( k D a}^{\mathbf{b}}$ & \\
\hline $\begin{array}{c}\mathrm{P}(3 \mathrm{HB}-c 0-95 \\
\text { mol\% } 4 \mathrm{HB})\end{array}$ & $23.2 \pm 4$ & $611.8 \pm 1$ & $226.6 \pm 20$ & $585 \pm 8$ & $132 \pm 11$ & $3.2 \pm 0.5$ \\
\hline
\end{tabular}

Values are mean \pm SD of three replicates; ${ }^{a}$ Determined using Gotech Al-3000 tensile Machine; ${ }^{b}$ Calculated from GPC analysis, $\mathrm{M}_{\mathrm{n}}$ : number-average molecular weight; $\mathrm{M}_{\mathrm{w}}$ : weight average molecular weight; $\mathrm{M}_{\mathrm{w}} / \mathrm{M}_{\mathrm{n}}$ : polydispersity index.

\subsection{Fabrication of SBCC and SCCC Scaffolds}

In this study a three-dimensional, porous scaffold was successfully engineered with the use of a combination of techniques, namely particle leaching and freeze-drying. Figure 1 shows a schematic of the fabrication of porous antimicrobial SSD-P(3HB-co-4HB)-collagen peptide scaffolds termed as SBCC and SCCC scaffolds. The system contained two phases in developing a highly porous, well interconnected pore structure of the scaffold. The first phase involved the particle leaching using $\mathrm{NaHCO}_{3}(200 \mu \mathrm{m})$, followed by the freezedrying technique. The combination of methods has shown many advantages over other methods as it is easier to control pore structures. This will produce porous scaffolds with open surface pores and interconnected bulk pores which will facilitate cell seeding and homogeneous cell distribution and promote tissue regeneration [26,27]. Despite the homogenous pores' structures, the surface properties of these polymers are hydrophobic which will possibly inhibit the infiltration of cell suspension into the scaffolds preventing smooth cell seeding.

Therefore, it is crucial to modify the surface characteristic from hydrophobic to hydrophilic to facilitate cell seeding. In this case, the surface of the porous $\mathrm{P}(3 \mathrm{HB}-\mathrm{co}-4 \mathrm{HB})$ scaffolds was coated with hydrophilic collagen peptide to increase the hydrophilicity of the surface, thus improving cell interaction [28-30]. In this study, apart from the surface modification of $\mathrm{P}(3 \mathrm{HB}-\mathrm{co}-4 \mathrm{HB})$ scaffold with collagen layer, incorporation of antimicrobial agent, SSD was carried out. This was executed by introducing the SSD either through blending (SBCC) or coating of the scaffolds (SCCC). Fabrication of scaffolds that release 
the antimicrobial agents or respond to infections is crucial in developing biomaterials in tissue engineering [31-33].
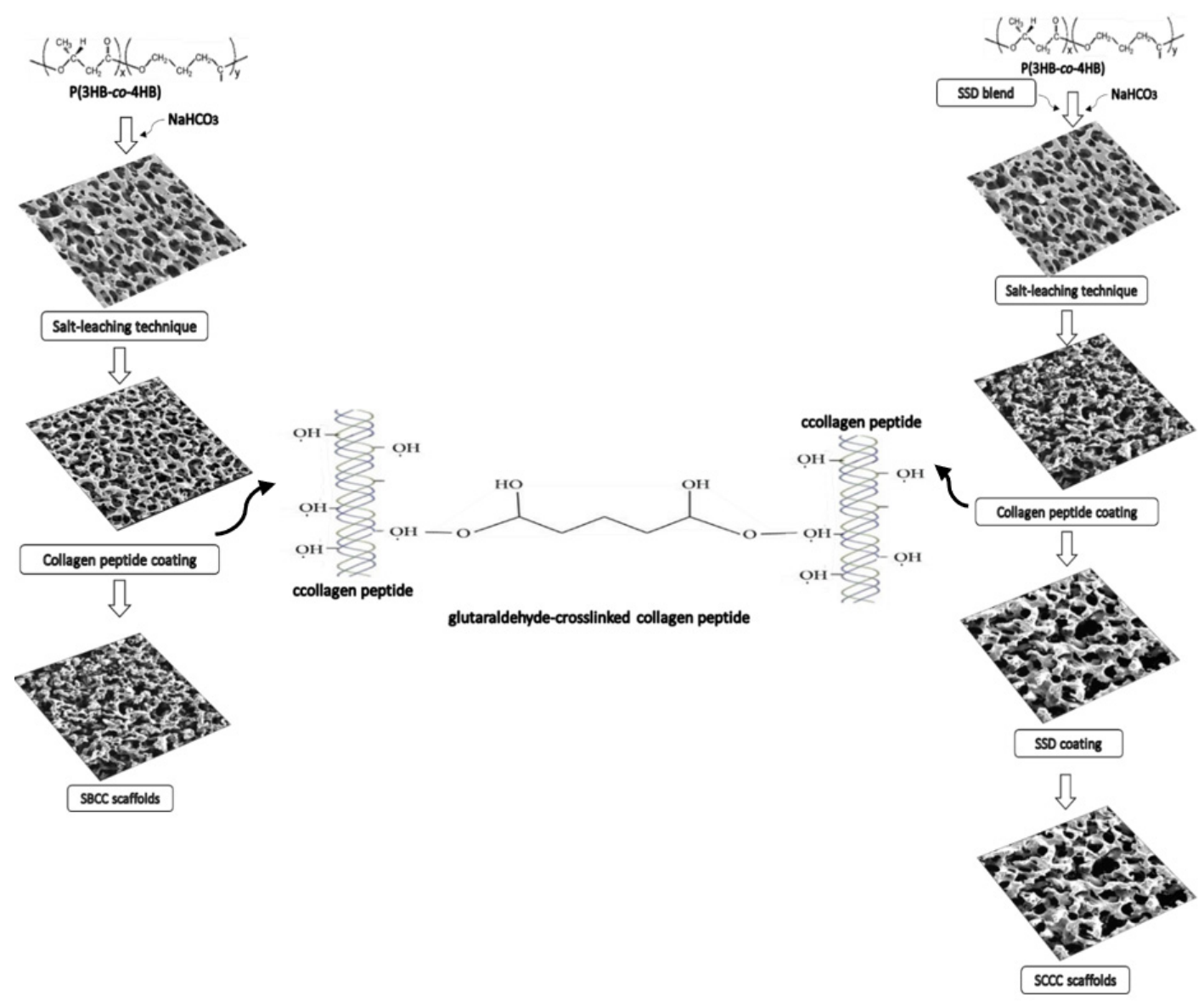

Figure 1. Schematic of fabrication of SBCC and SCCC scaffolds using a combination of salt leaching modification and freeze-drying technique with collagen peptide coating and cross-linking with glutaraldehyde.

Besides, surface morphology is crucial in developing biomaterials as this determines the cell-matrix interface interactions. As seen in Figure 2, the SEM micrographs reveal the formation of the three-dimensional interconnected porous structure of SBCC and SCCC scaffolds. Interestingly, the pore sizes observed using SEM were much smaller than the range of porogen sizes $\left(\mathrm{NaHCO}_{3}\right)$ used to create them. This could be attributed to the combination of techniques used, mainly freeze-drying. Hence, combining salt leaching with freeze-drying may enhance pore interconnectivity and assist the formation of homogenous pores ranging from 100 to $200 \mu \mathrm{m}$ [34]. However, SCCC scaffolds exhibited rougher appearance with less interconnection and possessed numerous macropores as compared to SBCC. Basically, the porous-based connectivity surface is favored to enhance the ECM architecture and provide a larger space to induce cell-material interactions [35-39]. Additionally, both the scaffolds created similar morphology with generally amorphous pores with smooth edge.

The fabricated scaffolds differed in terms of their construction. SSD coated onto the porous SCCC scaffolds showed solubility in aqueous medium in contrast to the impregnated collagen in SBCC. Hence, the collagen peptide coated $\mathrm{P}(3 \mathrm{HB}-\mathrm{co}-4 \mathrm{HB})$ porous scaffold were then cross-linked via GA vapor phase. The dissolution analysis on scaffolds of cross-linking and uncross-linking scaffolds were shown in Figure 3. The percentage of dissolutions was significantly higher for uncross-linked SCCC scaffolds with the amount retained only between $15 \%$ and $45 \%$. On the contrary, the crosslinked SSD/collagen peptide-coated $\mathrm{P}(3 \mathrm{HB}-\mathrm{co}-4 \mathrm{HB})$ scaffold exhibited collagen retain percentage from up to $80 \%$ 
to $90 \%$. This demonstrates that cross-linking with GA enhanced the scaffolds resistance to dissolution. After GA vapor cross-linking, the membranes became visibly yellowish and shrunk dimensionally. The aldimine linkages $(\mathrm{CH}=\mathrm{N})$ between the free amine groups of protein and GA attributes to the color change, whereas the covalent bond formed between the aldehyde groups of GA caused shrinkage $[40,41]$. The aldimine linkage was a reflection of Schiff base reaction, whereby the carbon in the aldehyde group of GA was attacked by nucleophilic nitrogen in the amino group of collagen peptides, and hence replaced the oxygen in the aldehyde group and eliminated water molecule [30]. Nonetheless, GA cross-linking with vapor phase methodology showed low or no detectable cytotoxic effects [25,42]. As described by Teixera et al. (2021), this will enable a sustainable approach in achieving green methodology and the lowest environment impact possible at all stages of fabrication for biomedical application [43].
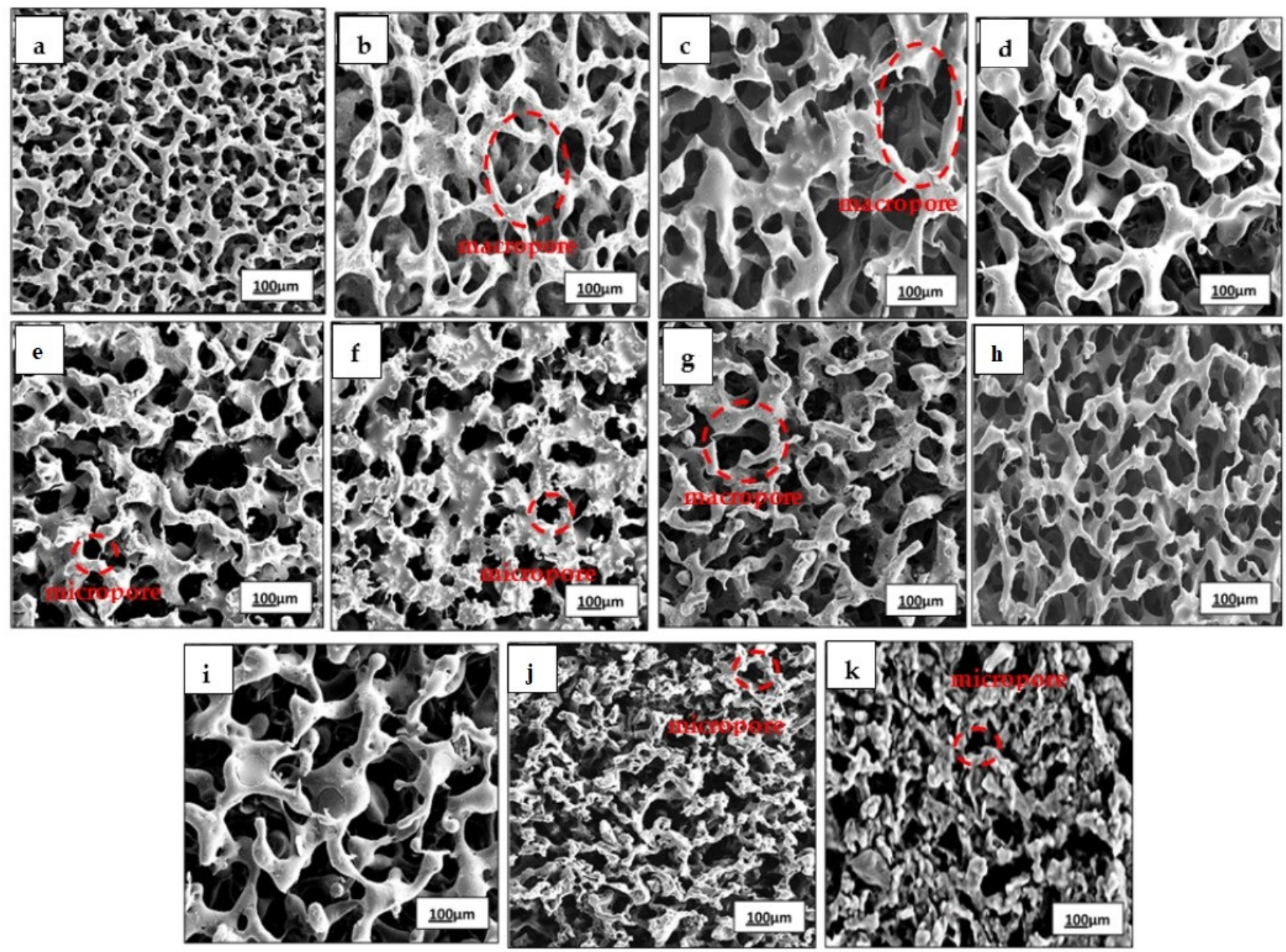

Figure 2. Micrograph of porous structure of (a) control-P(3HB-co-4HB), (b) SCCC $2.5 \mathrm{wt} . \%$, (c) SCCC $5 \mathrm{wt} . \%$, (d) SCCC 7.5 wt. $\%$, (e) SCCC 10 wt. \%, (f) SCCC 12.5 wt. \%, (g) SBCC 2.5 wt. \%, (h) SBCC 5 wt. \%, (i) SBCC 7.5 wt. \%, (j) SBCC 10 wt. \% and (k) SBCC 12 wt. $\%$. 


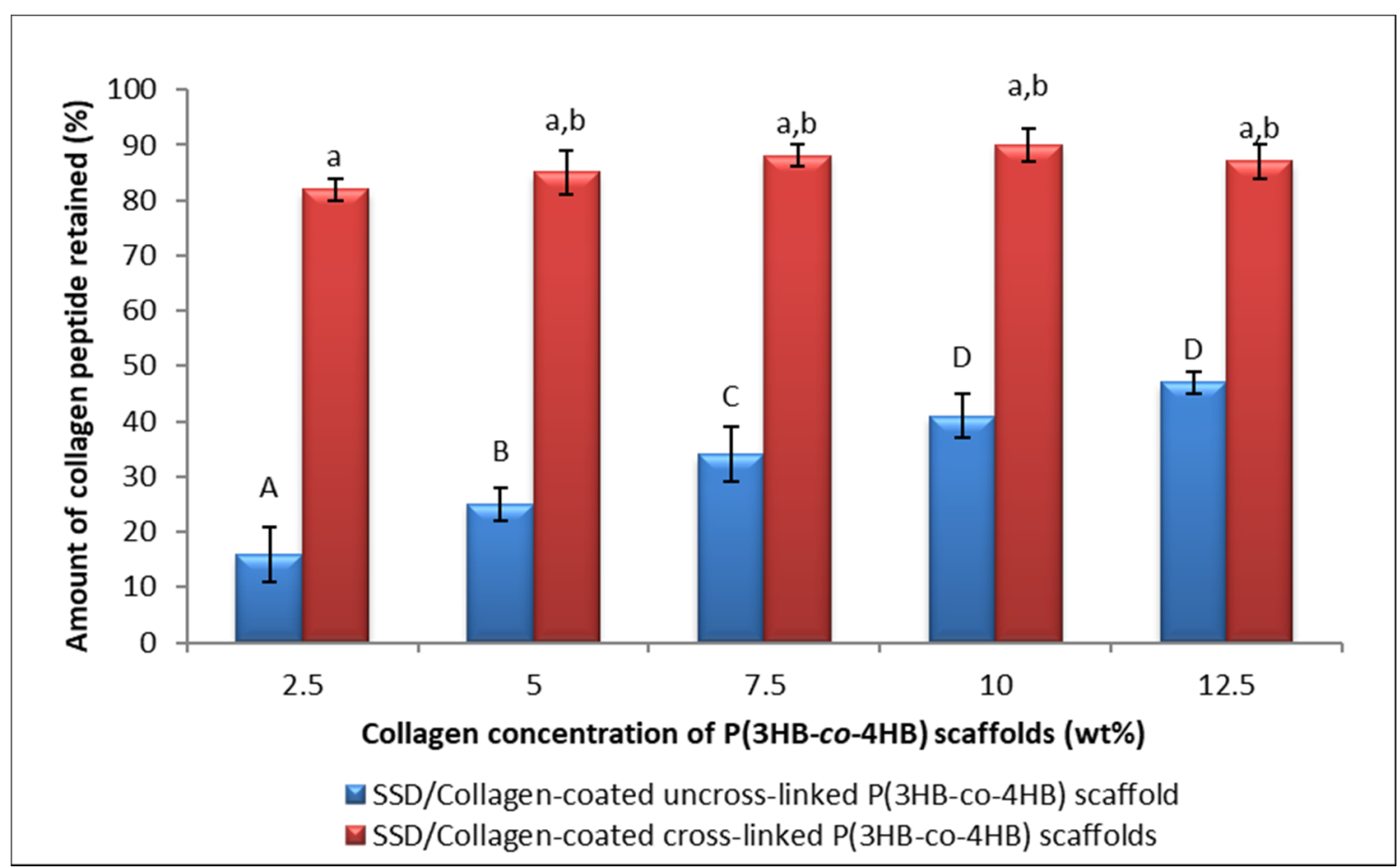

Figure 3. The percentage of collagen retained on cross-linked SCCC and uncross-linked SCCC scaffold. Data represent means $\pm \mathrm{SD}(n=3)$. Mean data accompanied by different alphabets as of cross-linked SCCC scaffolds (a-b); and uncross-linked SCCC (A-D) indicates significant difference within each respective group (Tukey's HSD test, $p<0.05$ ).

\subsection{Functional Group Identification Using FTIR Analysis}

FTIR analysis shown in Figure 4 was carried as an evidential analysis to determine and analyze the characteristic bands that correlate to functional groups of the fabricated scaffolds. The FTIR spectrum for collagen (a) showed symmetric and unsymmetric stretching of the primary amine $\left(\mathrm{NH}_{2}\right)$ bands at $3275 \mathrm{~cm}^{-1}$ and $3150 \mathrm{~cm}^{-1}$, respectively. The hydroxyl $(\mathrm{OH})$ from carboxylic acid portion also is expected to be overlapped with the symmetric amine at $3275 \mathrm{~cm}^{-1}$. The moderate peaks at $2937 \mathrm{~cm}^{-1}$ represent $\mathrm{CH}_{3}$ (bend) and $\mathrm{CH}_{2}$ (stretch) of the alkanes' substructure. A strong band at $1633 \mathrm{~cm}^{-1}$ represents $(\mathrm{C}=\mathrm{O})$ from the amide moiety. Another strong peak can be seen at $1531 \mathrm{~cm}^{-1}$ and represents $\mathrm{NH}_{2}$ bending [44-48]. The peaks of the $(\mathrm{C}=\mathrm{C})$ bands of the aromatic portion also can be clearly observed between the peaks of $1531 \mathrm{~cm}^{-1}$ to $1449 \mathrm{~cm}^{-1}$. In addition, a moderate peak at $920.89 \mathrm{~cm}^{-1}$ would represent a C-H (out-of-plane) band from the aromatics.

In the case of $\mathrm{P}(3 \mathrm{HB}-\mathrm{co}-4 \mathrm{HB})$ polymer (b), moderate peaks at $2963 \mathrm{~cm}^{-1}$ and $2899 \mathrm{~cm}^{1}$ represent $\mathrm{CH}_{3}$ (bend), $\mathrm{CH}_{2}$ (stretch) and $\mathrm{CH}$ of the alkanes' substructure. A strong band at $1633 \mathrm{~cm}^{-1}$ represents $(\mathrm{C}=\mathrm{O})$ and another strong band at $1161 \mathrm{~cm}^{-1}$ exhibits the (C-O) band $[8,49]$.

Comparatively, the FTIR spectra of SBCC (c) and SCCC (d) are rather comparable to each other as they exhibit all the expected bands and peaks of the designated collagen, $\mathrm{P}(3 \mathrm{HB}-\mathrm{co}-4 \mathrm{HB})$ polymer and pure SSD. The major characteristic absorption peaks in both FTIR spectra of SBCC (c) and SCCC (d) ca. 3283, 3150, 2900, 1719, 1630, 1540, 1450 and $1164 \mathrm{~cm}^{-1}$. The absorption peak at 3283 and $3150 \mathrm{~cm}^{-1}$ are assigned to $\mathrm{NH}_{2}$ symmetric and asymmetric stretching, respectively. A distinctive peak at $2900 \mathrm{~cm}^{-1}$ represents $\mathrm{CH}_{3}$ (bend) and $\mathrm{CH}_{2}$ (stretch) of the alkanes' substructure. Whilst the strong peak at $1719 \mathrm{~cm}^{-1}$ represents $(\mathrm{C}=\mathrm{O})$ peak. The absorption peak at $1630 \mathrm{~cm}^{-1}$ corresponds to $\mathrm{NH}_{2}$ bending. The peaks at $1540 \mathrm{~cm}^{-1}, 1450 \mathrm{~cm}^{-1}$ belong to the peaks of the $(\mathrm{C}=\mathrm{C})$ bands of the aromatic portion. The peaks of asymmetric stretching vibration of $\left(\mathrm{SO}_{2}\right)$ group cannot be resolved in these spectra as the band of $(\mathrm{C}-\mathrm{O})$ can be dominantly seen in this fingerprint region at $1164 \mathrm{~cm}^{-1}$ [50]. 
a)

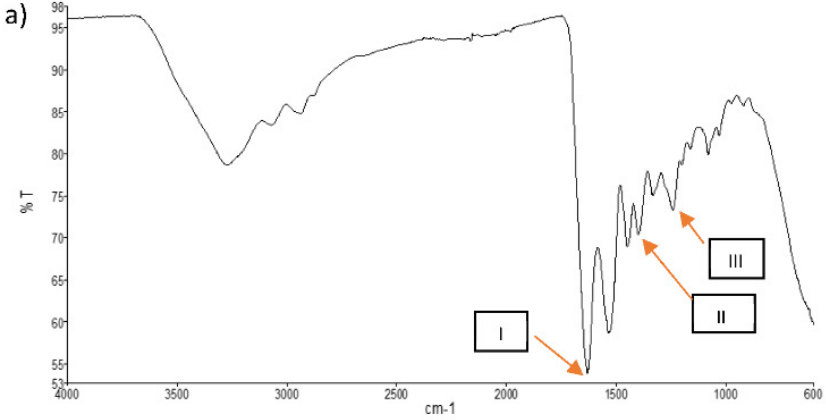

b)

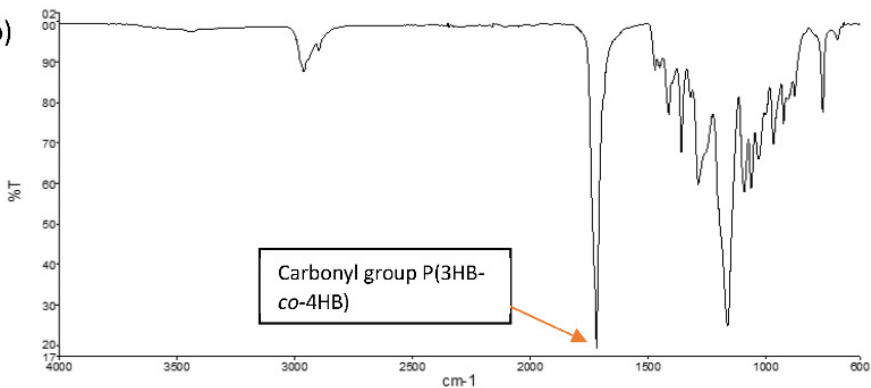

c)

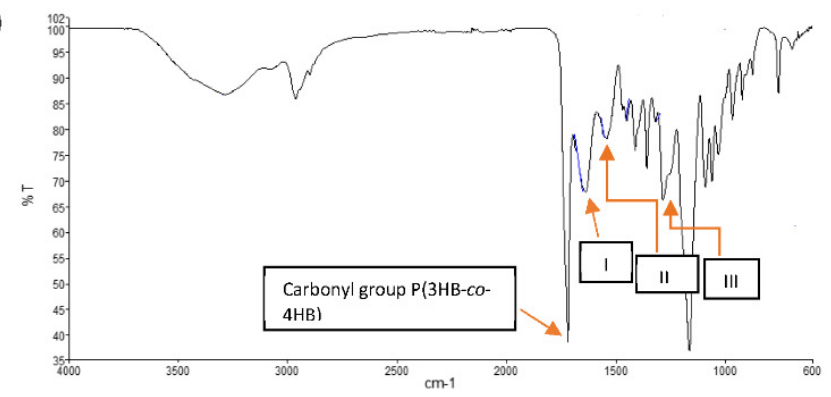

d)

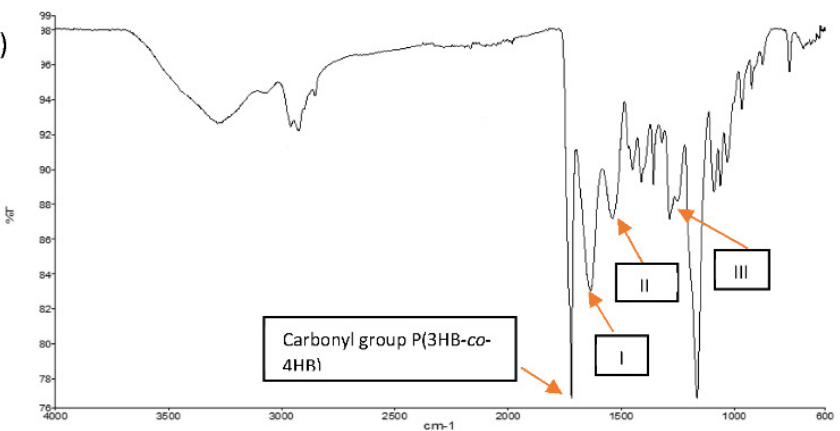

Figure 4. FTIR spectra of scaffolds (a) collagen, (b) P(3HB-co-4HB), (c) SBCC, and (d) SCCC. Arrows I, II, III indicate amide I, amide II and amide III, respectively.

It was observed that the prominent characteristic peaks of SBCC (c) and SCCC (d) with a few bands shift in comparison to each other with the dominant characteristics are from the $\mathrm{P}(3 \mathrm{HB}-\mathrm{co}-4 \mathrm{HB})$ polymer $(\mathrm{b})$ which are indicative of the reservation of the chemical aspect of these blends production. It can be concluded that the SSD did not engage with its active groups in any chemical interaction with any of the components of SBCC (c) and SCCC (d) built up. From the FTIR spectra of the two, there is also no evidence of electrostatic interaction nor chemical reaction have taken place between all the materials that made up the blend due to very little shift of all the vibrational wavenumbers (i.e., less than $5 \mathrm{~cm}^{-1}$ ) throughout the major bands of interest.

\subsection{Porosity Analysis}

The pores in scaffolds are imperative as they provide an ideal framework for cells to bind, proliferate and form extracellular matrix. As such, here the porosity was determined with six different collagen concentrations of the scaffolds. The fabricated scaffolds exhibited a gradual drop of the pore size from 145 to $53 \mu \mathrm{m}$ with increasing collagen concentrations (Figure 5). Similarly, the porosity of the SBCC declined by $50 \%$ from the control scaffold. This decrease in porosity could have been due to the larger collagen layer deposits on the surface of scaffolds [51-55]. Based on various studies, pore sizes above $100 \mu \mathrm{m}$ are ideal for cell infiltration and migration. Interestingly, $10 \mathrm{wt} . \%$ scaffolds resulted in a desirable pore size despite the higher concentration of collagen peptide. In developing biomaterial, pore structures of scaffolds play a crucial role in facilitating cell seeding, cell penetration and distribution in the scaffolds. Thus, the adhesion of cells and formation of new tissues and organs occurs [56-58]. It is emphasized that an ideal scaffold depends on biomaterial source, fabrication technique and the pore geometry. As such, it is vital to develop a scaffold with specific porosity properties for potential application in tissue engineering and regenerative medicine $[59,60]$. 


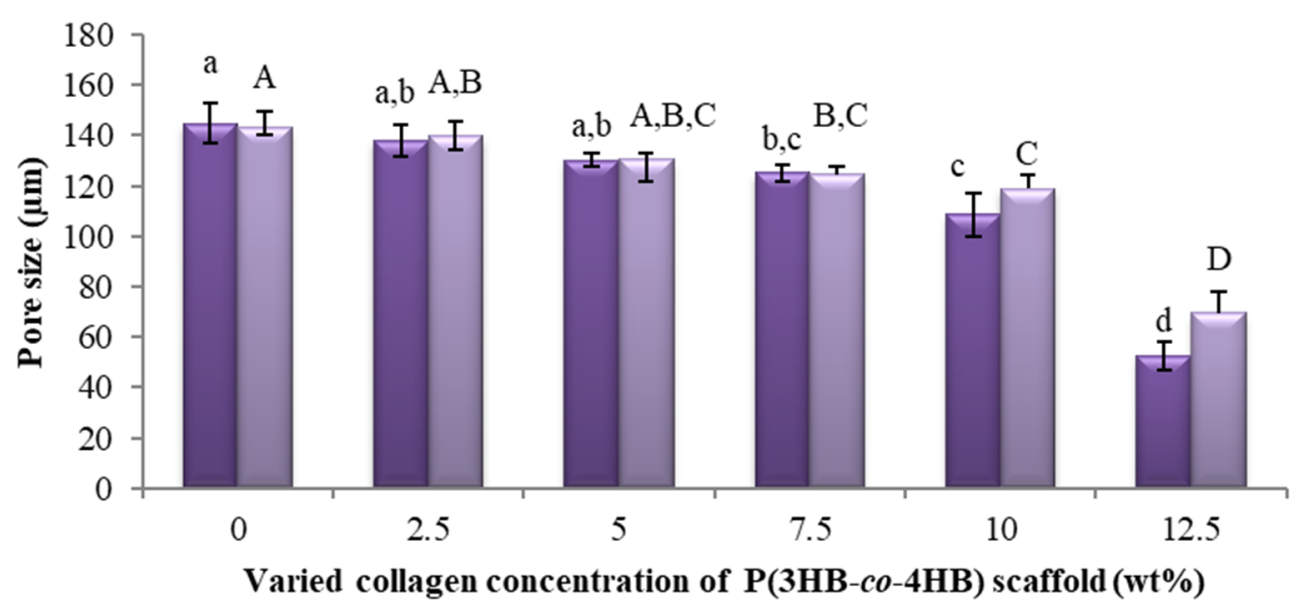

$\square \mathrm{SSD}$ coated/collagen coated $\mathrm{P}(3 \mathrm{HB}-\mathrm{co}-4 \mathrm{HB}) \square \mathrm{SSD}$ blend/collagen-coated $\mathrm{P}(3 \mathrm{HB}-\mathrm{co}-4 \mathrm{HB})$

Figure 5. Porosity analysis of SSD coated/collagen coated P(3HB-co-4HB); SCCC and SSD blend/collagen coated P(3HBco-4HB); SBCC scaffolds. Data represent means \pm SD $(n=3)$. Mean data accompanied by different alphabets as of SCCC scaffolds (a-d) and SBCC scaffolds (A-D) indicates significant difference within each respective group (Tukey's HSD test, $p<0.05)$.

\subsection{Hydrophilicity of Fabricated Scaffolds}

The hydrophilicity of the SCCC and SBCC scaffolds was determined using water contact angle analysis (Table 3). The graph clearly showed a decline in the contact angle as the concentration of collagen peptide increases, thus indicating the increase of hydrophilicity. Ideally, a contact angle of less than $90^{\circ}$ indicates that the surface is wet-prone, hence being categorized as a hydrophilic surface [61-63]. Whole wetting was observed with the water droplet becoming a flat puddle with $0^{\circ}$ contact angle on SBCC and SCCC with $10 \mathrm{wt} . \%$ and $12.5 \mathrm{wt} . \%$ collagen peptides. Additionally, the collagen peptide coating enhanced the surface wettability of sample scaffolds. The significant hydrophilicity enhancing effect of collagen peptide could be associated with the amino groups in collagen [64,65].

The wettability analysis of different sample collagen concentrations is demonstrated in Figure 6. A steady rise of water uptake percentage with the increment of collagen peptide concentrations can be observed. Water uptake ability elucidates the hydrophilicity of fabricated scaffolds which will increase the efficiency of absorption of essential supplements required for cell attachment. Overall, the collagen peptide coated $\mathrm{P}(3 \mathrm{HB}-\mathrm{co}-4 \mathrm{HB})$ scaffold absorbed a larger amount of water, exceeding $100 \%(v / v)$ of the total volume of the scaffold even at the low concentrations of collagen peptide ( $2.5 \mathrm{wt} . \%)$. As anticipated, the results pointed out that the hydrophilicity of both SCCC and SBCC scaffolds have similar water uptake ability. The water uptake ability properties of scaffolds are crucial in order to enhance the proliferation of a cell. The optimal design of a scaffold strongly depends on both materials and the surface treatment in modulating cell seeding and proliferation $[60,66]$.

\subsection{Evaluation of Cell Proliferation of Fibroblast Cells on Scaffolds}

In general, a functional scaffold requires the ability to support attachment and promote proliferation of cultured cells [67]. In line with it, the L929 fibroblasts cells behavior towards SCCC and SBCC scaffolds with different collagen concentrations was investigated as shown in Figure 7. Cells adhered well with progressive growth and by day three, the scaffold surfaces supported high cell density. The cell proliferation was spotted to increase significantly on scaffold coated with $2.5 \mathrm{wt} . \%$ until it reaches $10 \mathrm{wt} . \%$ as compared to the collagen free scaffold. However, the number of fibroblast cells decreased $\left(10.6 \times 10^{5}\right.$ cells $\left./ \mathrm{mL}\right)$ at the highest collagen peptide concentration (12.5 wt.\%). This may be attributed to the reduction of pore size, which caused less pore accessibility and proliferation $[8,30,68,69]$. 
In the current study, $10 \mathrm{wt} . \%$ collagen coated scaffold with pore size around $108.6 \pm 8.7 \mu \mathrm{m}$ demonstrated highest proliferation rate $\left(12.4 \times 10^{5}\right.$ cells $\left./ \mathrm{mL}\right)$, as shown in Figure 8 , in comparison to control, as well as $2.5 \mathrm{wt} . \%, 5 \mathrm{wt} . \%$ and $7.5 \mathrm{wt} . \%$ collagen coated scaffolds. In short, scaffolds fabricated using combined techniques displayed the highest cell proliferation. These findings clearly implied the enhancement of cell proliferation attributes to the effects of collagen on cell viability. In short, these findings clearly demonstrated the process of incorporating collagen layer on the scaffold is an efficient way to initiate cell attachment and supports cell growth [63,64].

Table 3. Water contact angle of scaffolds with various collagen peptide concentration.

\begin{tabular}{|c|c|c|}
\hline \multirow{2}{*}{ Collagen Peptide (wt.\%) } & \multicolumn{2}{|c|}{ Types of Scaffolds } \\
\hline & Coat/Coat & Blend/Coat \\
\hline \multicolumn{3}{|l|}{0} \\
\hline & $49.9 \pm 2.7$ & $73.3 \pm 1.4$ \\
\hline \multicolumn{3}{|l|}{2.5} \\
\hline & $32.5 \pm 2.8$ & $45.2 \pm 2.4$ \\
\hline \multicolumn{3}{|l|}{5.0} \\
\hline & $15.3 \pm 3.3$ & $25 \pm 5.4$ \\
\hline \multicolumn{3}{|l|}{7.5} \\
\hline & $8.58 \pm 0.8$ & $14.81 \pm 1.2$ \\
\hline
\end{tabular}

10.0 


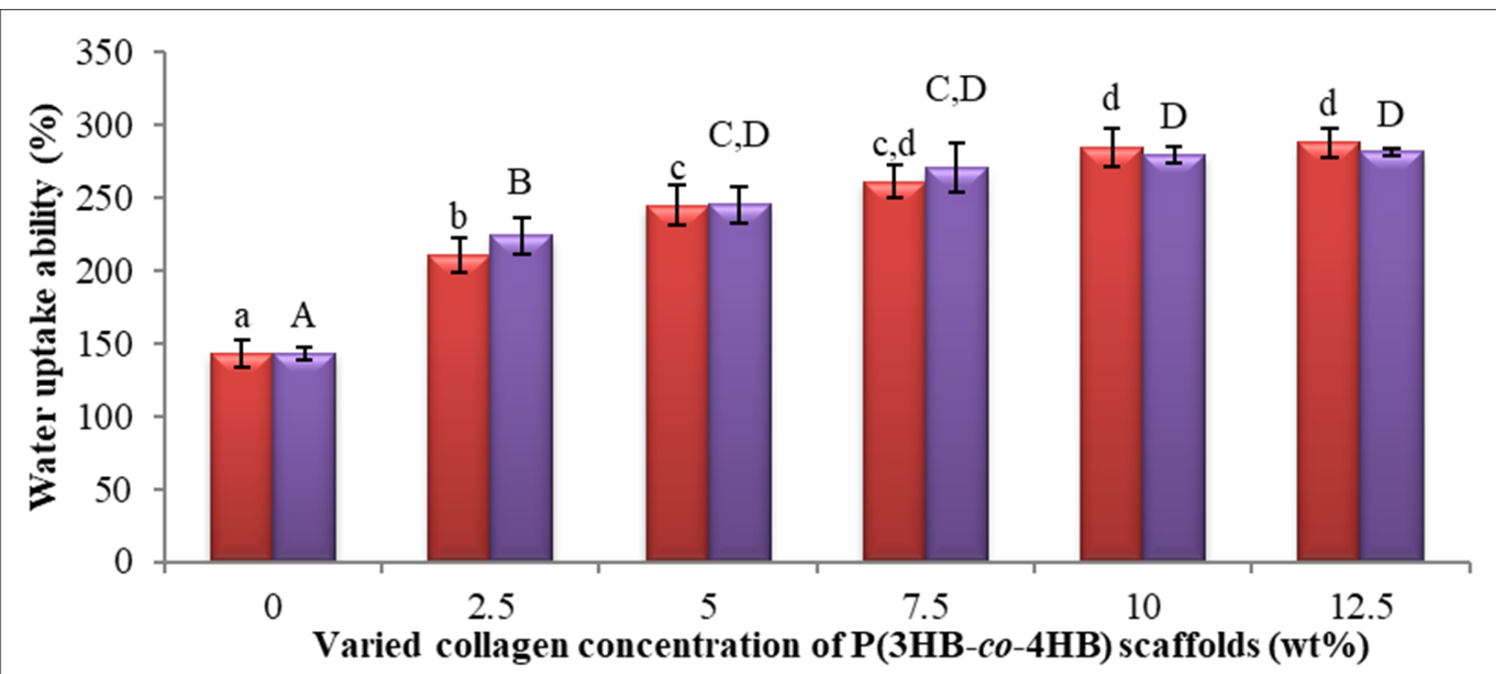

$\square \mathrm{SSD}$ coated /collagen coated $\mathrm{P}(3 \mathrm{HB}-\mathrm{co}-4 \mathrm{HB}) \square \mathrm{SSD}$ blend /collagen -coated $\mathrm{P}(3 \mathrm{HB}-\mathrm{co}-4 \mathrm{HB})$

Figure 6. Water uptake analysis of SSD coated/collagen coated $\mathrm{P}(3 \mathrm{HB}-\mathrm{co}-4 \mathrm{HB})$; SCCC and SSD blend/collagen coated $\mathrm{P}(3 \mathrm{HB}-\mathrm{co}-4 \mathrm{HB})$; SBCC scaffolds. Data represent means $\pm \mathrm{SD}(n=3)$. Mean data accompanied by different alphabets as of SCCC scaffolds (a-d) and SBCC scaffolds (A-D) indicates significant difference within each respective group (Tukey's HSD test, $p<0.05)$.

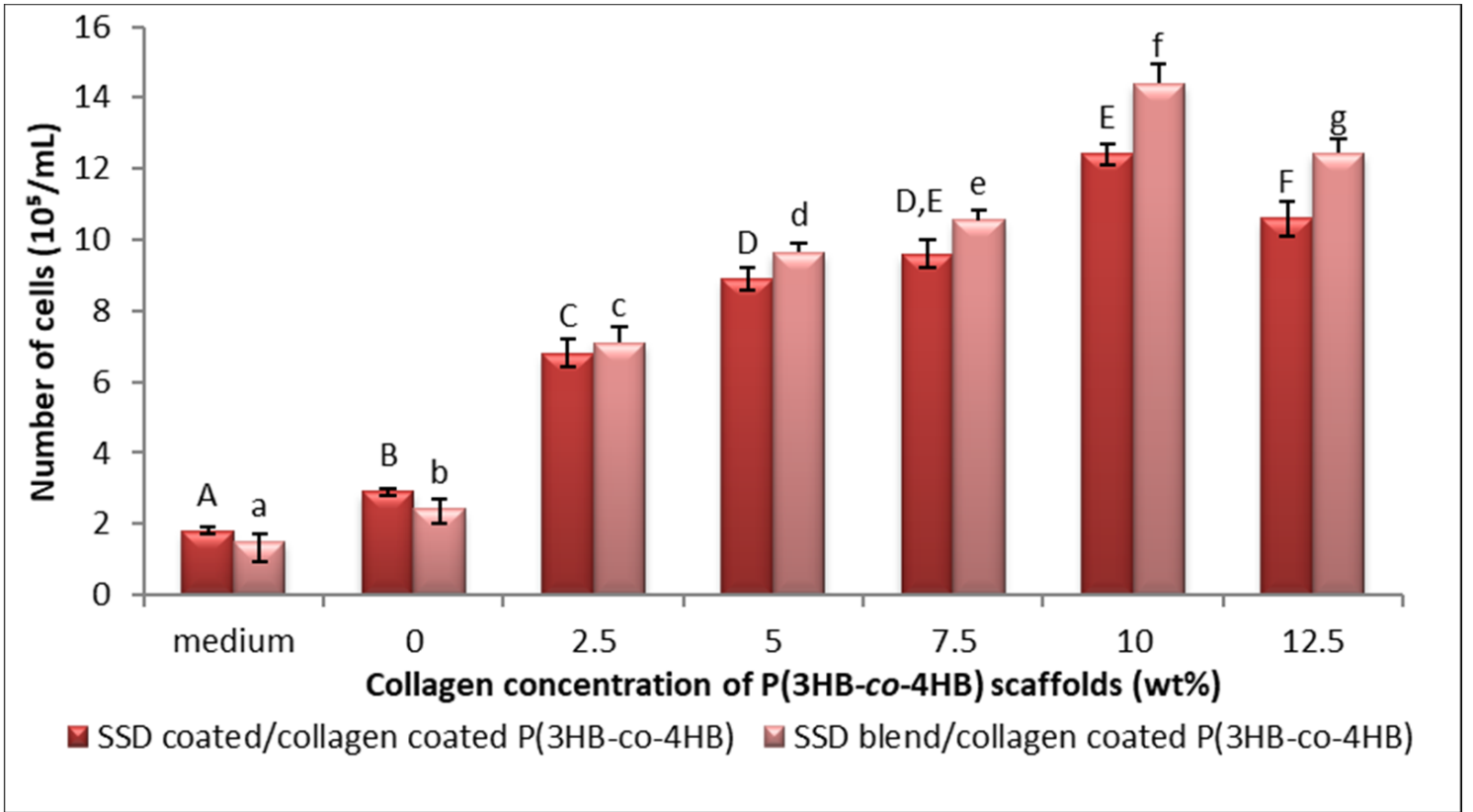

Figure 7. Proliferation of L929 cells on the SSD coated/collagen coated P(3HB-co-4HB); SCCC and SSD blend/collagen coated $\mathrm{P}(3 \mathrm{HB}-\mathrm{co}-4 \mathrm{HB})$; SBCC scaffolds. Data represent means $\pm \mathrm{SD}(n=3)$. Mean data accompanied by different alphabets as of SCCC scaffolds (A-F) and SBCC scaffolds (a-g) indicates significant difference within each respective group (Tukey's HSD test, $p<0.05)$ 


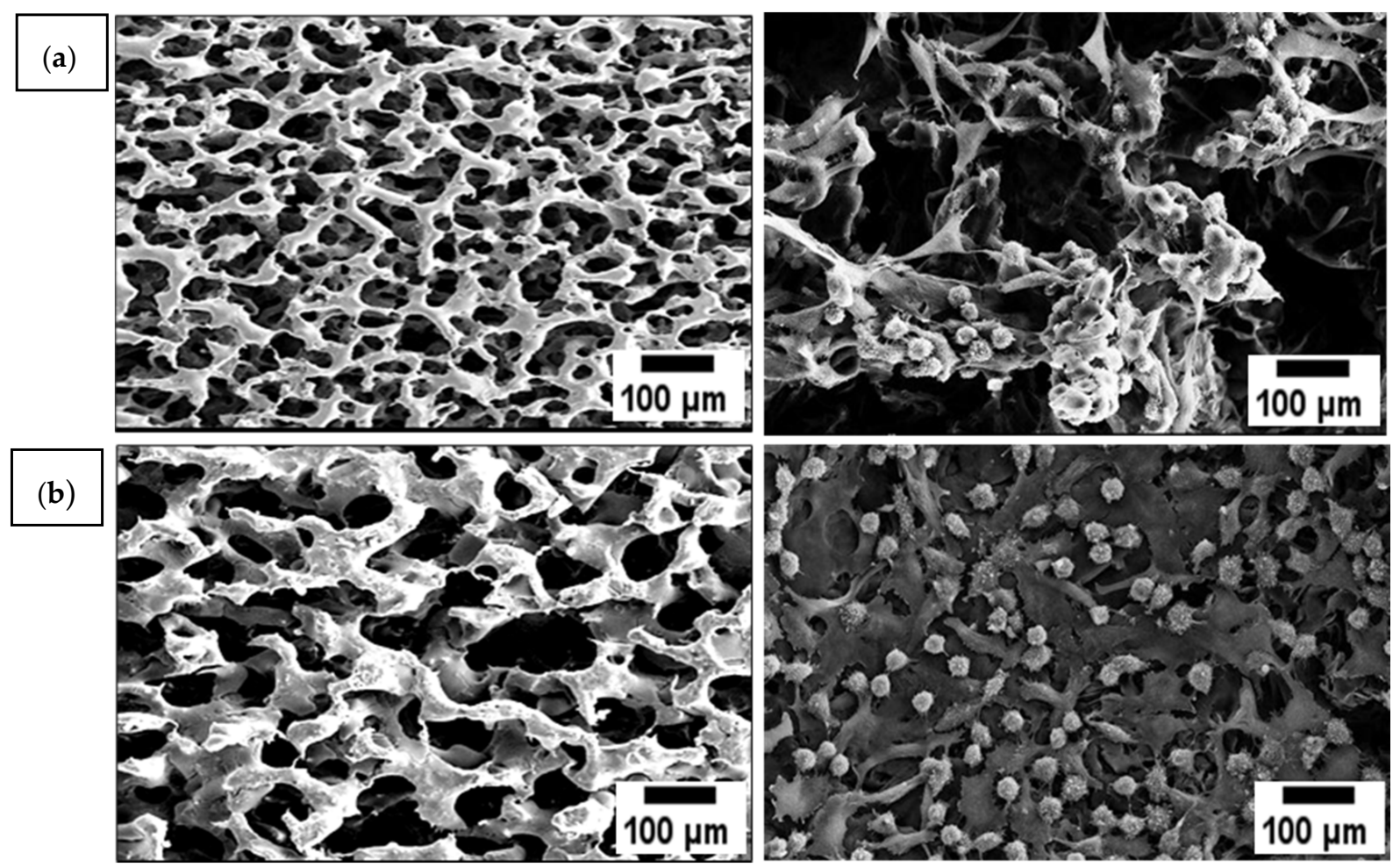

Figure 8. Micrograph of proliferation of L929 cells on (a) control-P(3HB-co-4HB), SCCC scaffolds (b) SCCC 10 wt.\%. Data represent means $\pm \mathrm{SD}(n=5)$.

\subsection{Antimicrobial Analysis of SCCC and SBCC Scaffolds}

Antimicrobial analysis was carried out using the colonization test as summarised in Table 4. Antimicrobial substance, silver sulfadiazine (SSD), was incorporated in the scaffolds. Silver compounds, especially (SSD), has been widely used as an antibacterial agent in various biomedical applications $[69,70]$. Based on the results obtained, both SCCC and SBCC scaffolds revealed desirable antimicrobial effects. However, SBCC scaffolds required $48 \mathrm{~h}$ to inhibit certain pathogenic microorganisms which was due to the elution of silver sulfurdiazine impregnated with SSD possessed, whereby Ag ions were physically entrapped in the scaffolds where controlled release of antimicrobial agent occurred [70]. Meanwhile, the results revealed that in SCCC with scaffolds, the silver ion was continuously released directly leading to almost $100 \%$ inhibition for most of the microorganism within $12 \mathrm{~h}$. Both scaffolds showed different functionality according to the releasing rate of silver ion. The schematic of the antimicrobial release of both the scaffolds is illustrated in Figure 9. The SCCC scaffolds, which rapidly release SSD, are thus appropriate for further work towards dermal application, especially skin damage to the epidermis and the upper dermis that can be regenerated spontaneously and healed in relatively shorter periods [71-74]. On the condition of chronic wounds, such as diabetic ulcers, long-term release of antimicrobials is highly suggested since regeneration occurs at the edges of injuries [75]. Therefore, the SBCC scaffold can be beneficial for such cases. The antimicrobial effect of SBCC scaffold is effective by the significantly prolonged release of silver ion, which continues to kill microbes after the release system is exhausted. The release of silver ions is accompanied by the contact killing of the layer that contains silver ion gradually released by diffusion and scaffold degradation [69]. Furthermore, according to Heo and coworkers [73], silver sulfadiazine binds with microbial DNA and releases the sulfonamide, interfering with the intermediary metabolic pathway [76]. 
Table 4. Antimicrobial test of SCCC and SBCC scaffolds against various microorganisms.

\begin{tabular}{ccccccccc}
\hline & \multicolumn{7}{c}{ Inhibition of Microorganisms (\%) } \\
\cline { 2 - 9 } Time (h) & \multicolumn{2}{c}{$\mathbf{6}$} & & $\mathbf{1 2}$ & $\mathbf{2 4}$ & $\mathbf{4 8}$ \\
\cline { 2 - 10 } & SCCC & SBCC & SCCC & SBCC & SCCC & SBCC & SCCC & SBCC \\
\hline $\begin{array}{c}\text { Staphylococus aerus } \\
\text { ATCC 12600 }\end{array}$ & $65 \pm 5$ & $13 \pm 1$ & $85 \pm 3$ & $36 \pm 5$ & $100 \pm 0$ & $83 \pm 8$ & NA & $100 \pm 0$ \\
\hline $\begin{array}{c}\text { Escherichia coli } \\
\text { ATCC 11303 }\end{array}$ & $79 \pm 8$ & $34 \pm 5$ & $100 \pm 0$ & $51 \pm 9$ & $100 \pm 0$ & $92 \pm 6$ & NA & $100 \pm 0$ \\
\hline $\begin{array}{c}\text { Pseudomonas aeruginosa } \\
\text { ATCC 17588 }\end{array}$ & $85 \pm 7$ & $43 \pm 9$ & $100 \pm 0$ & $45 \pm 5$ & $100 \pm 0$ & $87 \pm 12$ & NA & $100 \pm 0$ \\
\hline $\begin{array}{c}\text { Bacillus licheniformis } \\
\text { Candida albicans }\end{array}$ & $98 \pm 2$ & $65 \pm 10$ & $100 \pm 0$ & $95 \pm 5$ & $100 \pm 0$ & $100 \pm 0$ & NA & $100 \pm 0$ \\
\hline
\end{tabular}

Values are mean \pm SD of three replicates; NA denotes not applicable.

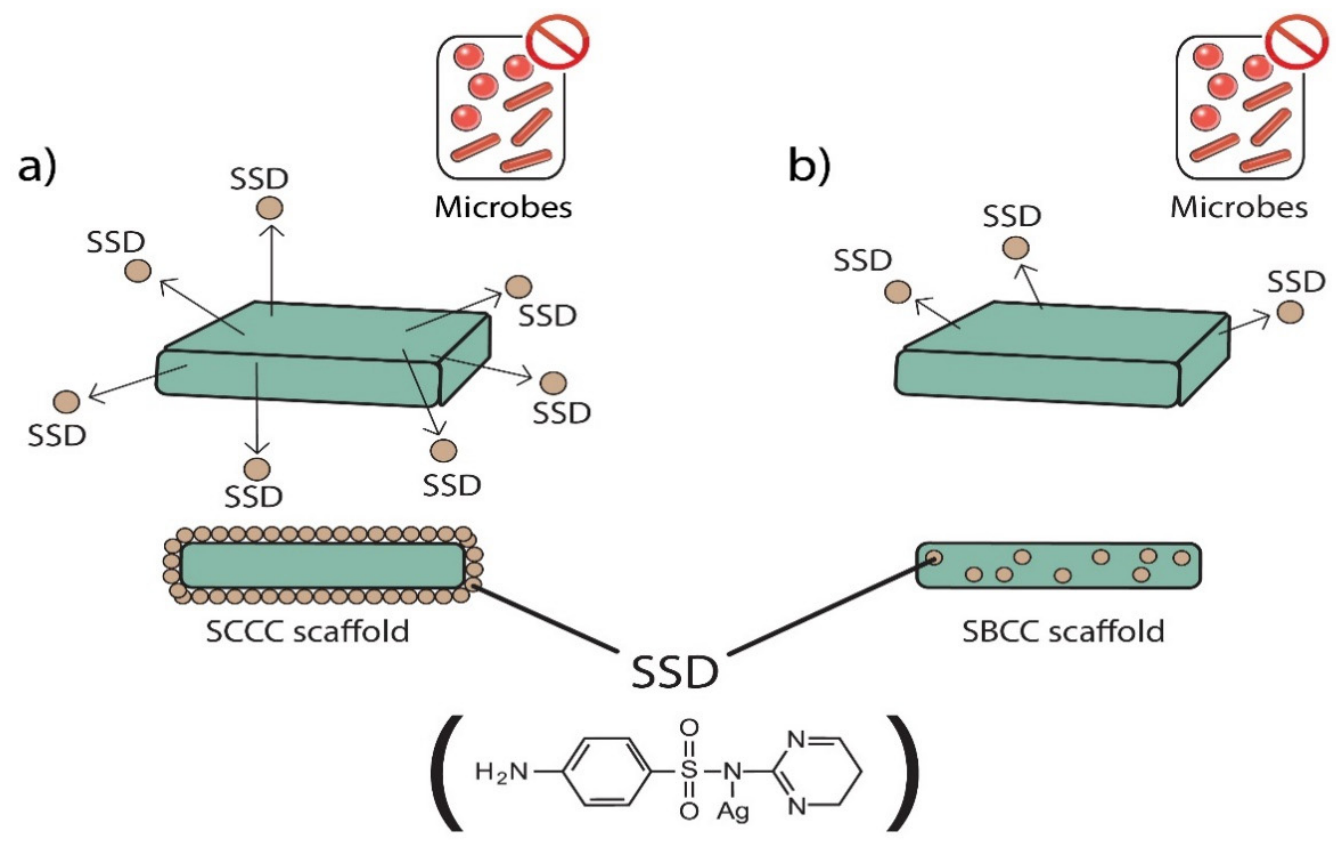

Figure 9. Schematic represents the releasing rate of silver ion from (a) SCCC scaffolds which rapidly release SSD and (b) the slow release of silver ion impregnated in the SBCC scaffolds.

\section{Conclusions}

In this study, we demonstrated that a combination of a simple and green approach to fabricate collagen and SSD incorporated $\mathrm{P}(3 \mathrm{HB}-\mathrm{co}-4 \mathrm{HB})$ scaffolds using porogen leaching and freeze-drying techniques. In comparing the SCCC and SBCC scaffolds, both the scaffolds differed in the incorporation of antimicrobial agent. Biomaterial based microbial infections pose serious concerns in the biomedical field. This study focuses on the development of highly efficient potential biomaterials that release the antimicrobial agents. This is in response to the limitations caused by some biomaterials with antimicrobial properties that inhibit microbial infections but slow down the cell seeding and tissue integration. Here, both the SCCC and SBCC scaffolds enhanced cell seeding and proliferation of L929 cells. Nonetheless, SCCC has higher antibacterial efficiency within the first $24 \mathrm{~h}$, whereby the antibiotic is rapidly released as compared to the controlled release of the antimicrobial properties in SBCC scaffolds. Entrapment of SSD in P(3HB-co-4HB), as in SBCC, resulted in a reduced burst release of SSD as compared to SCCC. Nonetheless, both the SCCC and SBCC scaffolds could be an excellent candidate to inhibit microbial colonization based on 
the biomaterial application without causing antibiotic resistance. The study provides evidence and elucidates the surface interface-cell interactions of the modified $\mathrm{P}(3 \mathrm{HB}-\mathrm{co}-4 \mathrm{HB})$ scaffolds and release of the antimicrobial agent from the scaffolds, thus paving the way in developing infection-resistance biomaterials in the biomedical field in the future.

Author Contributions: Conceptualization, A.-A.A.A. and S.V.; methodology, T.P.G.; validation, T.P.G., A.-A.A.A., S.V. and W.M.K.; formal analysis, T.P.G. and S.V.; investigation, T.P.G.; resources, A.-A.A.A.; data curation, T.P.G., W.M.K., S.V.; writing—original draft preparation, S.V.; writingreview and editing, S.V. and S.R.; visualization, A.-A.A.A., A.K.H.P.S. and S.R.; supervision, A.-A.A.A.; project administration, T.P.G.; funding acquisition, A.-A.A.A. All authors have read and agreed to the published version of the manuscript.

Funding: We would like to acknowledge Universiti Sains Malaysia (USM) for the research fund provided (311.PCCB.411954, 'USM-Strategic Initiative-Ten Q1-Q2').

Institutional Review Board Statement: Not applicable.

Informed Consent Statement: Not applicable.

Data Availability Statement: The data presented in this study is openly available.

Conflicts of Interest: The authors declare no conflict of interest.

\section{References}

1. Pina, S.; Ribeiro, V.P.; Marques, C.F.; Maia, F.R.; Silva, T.H.; Reis, R.L.; Oliveira, J.M. Scaffolding Strategies for Tissue Engineering and Regenerative Medicine Applications. Materials 2019, 12, 1824. [CrossRef] [PubMed]

2. Abdulghani, S.; Mitchell, G.R. Three-dimensional Scaffolds for Tissue Engineering Applications: Role of Porosity and Pore Size. Biomolecules 2019, 9, 750. [CrossRef] [PubMed]

3. Salim, Y.S.; Sharon, A.; Vigneswari, S.; Mohd Ibrahim, M.N.; Amirul, A.A. Environmental degradation of microbial polyhydroxyalkanoates and oil palm-based composites. Appl. Bichem. Biotechnol. 2012, 167, 314. [CrossRef] [PubMed]

4. Winnacker, M. Polyhydroxyalkanoates: Recent Advances in Their Synthesis and Applications. Eur. J. Lipid Sci. Technol. 2019, 121, 1900101. [CrossRef]

5. Trakunjae, C.; Boondaeng, A.; Apiwatanapiwat, W.; Kosugi, A.; Arai, T.; Sudesh, K.; Vaithanomsat, P. Enhanced Polyhydroxybutyrate (PHB) Production by Newly Isolated Rare Actinomycetes Rhodococcus sp. strain BSRT1-1 using Response Surface Methodology. Sci. Rep. 2021, 11, 1896. [CrossRef] [PubMed]

6. Akinmulewo, A.B.; Nwinyi, O.C. Polyhydroxyalkanoate: A Biodegradable Polymer (a mini review). J. Phys. Conf. Ser. 2019, 1378, 042007. [CrossRef]

7. Faezah, A.N.; Rahayu, A.; Vigneswari, S.; Majid, M.I.A.; Amirul, A.A. Regulating the molar fraction of 4-hydroxybutyrate in Poly(3-hydroxybutyrate-co-4-hydroxybutyrate) by biological fermentation and enzymatic degradation. World J. Microbiol. Biotechnol. 2011, 27, 2455. [CrossRef]

8. Vigneswari, S.; Chai, J.M.; Kamarudin, K.H.; Amirul, A.A.; Focarate, M.L.; Ramakrishna, S. Elucidating the Surface Functionality of Biomimetic RGD Peptides Immobilized on Nano-P(3HB-co-4HB) for H9c2 Myoblast Cell Proliferation. Front. Bioeng. Biotechnol. 2020, 8, 567693. [CrossRef]

9. Vigneswari, S.; Gurusamy, T.P.; Abdul Khalil, H.P.S.; Ramakrishna, S.; Amirul, A.A. Elucidation of Antimicrobial SSD blend/poly (3-hydroxybutyrate-co-4-hydroxybutyrate) Immobilised with Collagen Peptide As Potential Biomaterial. Polymer 2020, 12, 2979. [CrossRef]

10. Sun, F.; Guo, J.; Liu, Y.; Yu, Y. Preparation and Characterization of Poly (3-hydroxybutyrate-co-4-hydroxybutyrate)/PullulanGelatin Electrospun Nanofibers with Shell-Core Structure. Biomed. Mater. 2020, 15, 045023. [CrossRef]

11. Lim, Y.S.; Ok, Y.J.; Hwang, S.Y.; Kwak, J.Y.; Yoon, S. Marine Collagen as A Promising Biomaterial for Biomedical Applications. Mar. Drugs 2019, 17, 467. [CrossRef]

12. Hernandez-Gordillo, V.; Chmielewski, J. Mimicking the Extracellular Matrix with Functionalized, Metal-Assembled Collagen Peptide Scaffolds. Biomaterials 2014, 35, 7363-7373. [CrossRef]

13. Yamada, S.; Yamamoto, K.; Ikeda, T.; Yanagiguchi, K.; Hayashi, Y. Potency of Fish Collagen as a Scaffold for Regenerative Medicine. BioMed Res. Int. 2014, 2014, 302932. [CrossRef]

14. Xiao, X.; Zhao, W.; Liang, J.; Sauer, K.; Libera, M. Self-Defensive Antimicrobial Biomaterial Surfaces. Colloids Surf. B Biointerfaces 2020, 192, 110989. [CrossRef]

15. Ilomuanya, M.O.; Adebona, A.C.; Wang, W.; Sowemimo, A.; Eziegbo, C.L.; Silva, B.O.; Adeosun, S.O.; Joubert, E.; De Beer, D. Development and Characterization of Collagen-Based Electrospun Scaffolds Containing Silver Sulphadiazine and Aspalathus linearis Extract for Potential Wound Healing Applications. SN Appl. Sci. 2020, 2, 881. [CrossRef]

16. Mehta, M.A.; Shah, S.; Ranjan, V.; Sarwade, P.; Philipose, A. Comparative Study of Silver-Sulfadiazine-Impregnated Collagen Dressing Versus Conventional Burn Dressings in Second-Degree Burns. J. Fam. Med. Prim. Care 2019, 8, $215-219$. 
17. Banerjee, J.; Seetharaman, S.; Wrice, N.L.; Christy, R.J.; Natesan, S. Delivery of Silver Sulfadiazine and Adipose Derived Stem Cells Using Fibrin Hydrogel Improves Infected Burn Wound Regeneration. PLoS ONE 2019, 14, e0217965. [CrossRef]

18. Ceresa, C.; Fracchia, L.; Marchetti, A.; Rinaldi, M.; Bosetti, M. Injectable Scaffolds Enriched with Silver to Inhibit Bacterial Invasion in Tissue Regeneration. Materials 2019, 12, 1931. [CrossRef]

19. Shanmugasundaram, N.; Sundaraseelan, J.; Uma, S.; Selvaraj, D.; Babu, M. Design and Delivery of Silver Sulfadiazine from Alginate Microspheres-Impregnated Collagen Scaffold. J. Biomed. Mater. Res. B Appl. Biomater. 2006, 77, 378-388. [CrossRef]

20. Nejaddehbashi, F.; Hashemitabar, M.; Bayati, V.; Moghimipour, E.; Movaffagh, J.; Orazizadeh, M.; Abbaspour, M.R. Incorporation of Silver Sulfadiazine into an Electrospun Composite of Polycaprolactone as An Antibacterial Scaffold for Wound Healing in Rats. Cell J. 2020, 21, 379-390.

21. Mohseni, M.; Shamloo, A.; Aghababaei, Z.; Vossoughi, M.; Moravvej, H. Antimicrobial Wound Dressing Containing Silver Sulfadiazine with High Biocompatibility: In Vitro Study. Artif. Organs 2016, 40, 765-773. [CrossRef]

22. Malafatti, J.O.D.; Bernardo, M.P.; Moreira, F.K.V.; Ciol, H.; Inada, N.M.; Mattoso, L.H.C.; Paris, E.C. Electrospun Poly (lactic acid) Nanofibers Loaded with Silver Sulfadiazine/[Mg-Al]-Layered Double Hydroxide As An Antimicrobial Wound Dressing. Polym. Adv. Technol. 2020, 31, 1377-1387. [CrossRef]

23. Huong, K.H.; Azuraini, M.J.; Aziz, N.A.; Amirul, A.A. Pilot scale production of poly (3-hydroxybutyrate-co-4-hydroxybutyrate) biopolymers with high molecular weight and elastomeric properties. J. Biosci. Bioeng. 2017, 124, 76-83. [CrossRef]

24. Norhafini, H.; Thinagaran, L.; Shantini, K.; Huong, K.H.; Syafiq, I.M.; Bhubalan, K.; Amirul, A.A. Synthesis of Poly (3hydroxybutyrate-co-4-hydroxybutyrate) with High 4HB Composition and PHA Content Using 1,4-butanediol and 1,6-hexanediol for Medical Application. J. Polym. Res. 2017, 24, 24-189. [CrossRef]

25. Destaye, A.G.; Lin, C.K.; Lee, C.K. Glutaraldehyde Vapor Cross-Linked Nanofibrous PVA Mat with In Situ Formed Silver Nanoparticles. ACS Appl. Mater. Interfaces 2013, 5, 4745-4752. [CrossRef]

26. Aramwit, P.; Ratanavaraporn, J.; Ekgasit, S.; Tongsakul, D.; Bang, N.A. Green Salt-Leaching Technique to Produce Sericin/ PVA/Glycerin Scaffolds with Distinguished Characteristics for Wound-Dressing Applications. J. Biomed. Mater. Res. B 2015, 103, 915-924. [CrossRef]

27. Wang, Y.; Ke, Y.; Ren, L.; Wu, G.; Chen, X.; Zhao, Q. Surface engineering of PHBV by covalent collagen immobilization to improve cell compatibility. J. Biomed. Mater. Res. A 2009, 88, 616-627. [CrossRef]

28. Köse, G.T.; Kenar, H.; Hasirci, N.; Hasirci, V. Macroporous poly (3-hydroxybutyrate-co-3-hydroxyvalerate) matrices for bone tissue engineering. Biomaterials 2003, 24, 1949-1958. [CrossRef]

29. Ismail, I.; Gurusamy, T.P.; Ramachandran, H.; Amirul, A.A. Enhanced production of poly (3-hydroxybutyrate-co-4hydroxybutyrate) copolymer and antimicrobial yellow pigmentation from Cupriavidus sp. USMAHM13 with antibiofilm capability. Prep. Biochem. Biotechnol. 2017, 47, 388-396. [CrossRef]

30. Vigneswari, S.; Murugaiyah, V.; Kaur, G.; Abdul Khalil, H.P.S.; Amirul, A.A. Biomacromolecule Immobilization: Grafting of Fish-Scale Collagen Peptides onto Aminolyzed P(3HB-co-4HB) Scaffolds as A Potential Wound Dressing. Biomed. Mater. 2016, 68, 1927-1934. [CrossRef]

31. Ahmed, W.; Zhai, Z.; Gao, C. Adaptive Antibacterial Biomaterial Surfaces and Their Applications. Mater. Today Bio 2019, 2, 100017. [CrossRef] [PubMed]

32. Wieszczycka, K.; Staszak, K.; Woźniak-Budych, M.J.; Litowczenko, J.; Maciejewska, B.M.; Jurga, S. Surface Functionalization-The Way for Advanced Applications of Smart Materials. Coord Chem. Rev. 2021, 436, 213846. [CrossRef]

33. Zhu, Y.; Ke, J.; Zhang, L. Anti-biofouling and antimicrobial biomaterials for tissue engineering. In Racing for the Surface; Li, B., Moriarty, T., Webster, T., Xing, M., Eds.; Springer: New York, NY, USA, 2020.

34. Goswami, M.; Rekhi, P.; Debnath, M.; Ramakrishna, S. Microbial Polyhydroxyalkanoates Granules: An Approach Targeting Biopolymer for Medical Applications and Developing Bone Scaffolds. Molecules 2021, 26, 860. [CrossRef] [PubMed]

35. Bružauskaite, I.; Bironaite, D.; Bagdonas, E.; Bernotienè, E. Scaffolds and cells for tissue regeneration: Different scaffold pore sizes-Different cell effects. Cytotechnology 2016, 68, 355-369. [CrossRef] [PubMed]

36. Liao, C.J.; Chen, C.F.; Chen, J.H.; Chiang, S.F.; Lin, Y.J.; Chang, K.Y. Fabrication of Porous Biodegradable Polymer Scaffolds Using a Solvent Merging/Particulate Leaching Method. J. Biomed. Mater. Res. 2002, 59, 676-681. [CrossRef] [PubMed]

37. Subia, B.; Kundu, J.C.S. Biomaterial Scaffold Fabrication Techniques for Potential Tissue Engineering Applications. Tissue Eng. 2010, 141, 20-31.

38. Ho, M.H.; Kuo, P.Y.; Hsieh, H.J.; Hsien, T.Y.; Hou, L.T.; Lai, J.Y.; Wang, D.M. Preparation of Porous Scaffolds by Using FreezeExtraction and Freeze-Gelation Methods. Biomaterials 2004, 25, 129-138. [CrossRef]

39. Wang, Z.; Qing, Q.; Chen, X.; Liu, C.; Luo, J.; Hu, J.; Qin, T. Effects of Scaffold Surface Morphology on Cell Adhesion and Survival Rate in Vitreous Cryopreservation of Tenocyte-Scaffold Constructs. Appl. Surf. Sci. 2016, 388, 223-227. [CrossRef]

40. Zhu, B.; Li, W.; Chi, N.; Lewis, R.V.; Osamor, J.; Wang, R. Optimization of Glutaraldehyde Vapor Treatment for Electrospun Collagen/Silk Tissue Engineering Scaffolds. ACS Omega 2017, 2, 2439-2450. [CrossRef]

41. Campiglio, C.E.; Negrini, N.C.; Farè, S.; Draghi, L. Cross-linking Strategies for Electrospun Gelatin Scaffolds. Materials 2019, 12, 2476. [CrossRef]

42. Vashisth, P.; Pruthi, V. Synthesis and Characterization of Crosslinked Gellan/PVA Nanofibers for Tissue Engineering Application. Mater. Sci. Eng. C 2016, 67, 304-312. [CrossRef] 
43. Teixeira, M.A.; Antunes, J.C.; Amorimm, M.T.P.; Felgueiras, H.P. Green Optimization of Glutaraldehyde Vapor-Based Crosslinking on Poly (Vinyl Alcohol)/Cellulose Acetate Electrospun Mats for Applications as Chronic Wound Dressings. Proceedings 2021, 69, 30. [CrossRef]

44. Bettini, S.; Bonfrate, V.; Syrgiannis, Z.; Sannino, A.; Salvatore, L.; Madaghiele, M.; Valli, L.; Giancane, G. Biocompatible Collagen Paramagnetic Scafold For Controlled Drug Release. Biomacromolecules 2015, 16, 2599-2608. [CrossRef]

45. Bonfrate, V.; Manno, D.; Serra, A.; Salvatore, L.; Sannino, A.; Buccolieri, A.; Serra, T.; Giancane, G. Enhanced Electrical Conductivity of Collagen Films Through Long-Range Aligned Iron Oxide Nanoparticles. J. Colloid Interface Sci. 2017, 501, 185-191. [CrossRef]

46. Terzi, A.; Storelli, E.; Bettini, S.; Sibillano, T.; Altamura, D.; Salvatore, L.; Madaghiele, M.; Romano, A.; Siliqi, D.; Ladisa, M.; et al. Effects of Processing on Structural, Mechanical and Biological Properties of Collagen-Based Substrates for Regenerative Medicine. Sci. Rep. 2018, 8, 1429. [CrossRef]

47. Riaz, T.; Zeeshan, R.; Zarif, F.; Ilyas, K.; Muhammad, N.; Safi, S.Z.; Rahim, A.; Rizvi, S.A.A.; Rehman, I.U. FTIR Analysis of Natural and Synthetic Collagen. Appl. Spectrosc. Rev. 2018, 53, 703-746. [CrossRef]

48. Sotelo, C.G.; Comesaña, M.B.; Ariza, P.R.; Pérez-Martín, R.I. Characterization of Collagen from Different Discarded Fish Species Of The West Coast of the Iberian Peninsula. J. Aquat. Food Prod. Technol. 2016, 25, 388-399. [CrossRef]

49. Zhijiang, C.; Qin, Z.; Xianyou, S.; Yuanpei, L. Zein/poly (3-hydroxybutyrate-co-4-hydroxybutyrate) Electrospun Blend Fiber Scaffolds: Preparation, Characterization and Cytocompatibility. Mater. Sci. Eng. C Mater. Biol. Appl. 2017, 1, 797-806. [CrossRef]

50. Bayari, S.; Severcan, F. FTIR Study of Biodegradable Biopolymers: P(3HB), P(3HB-co-4HB) and P(3HB-co-3HV). J. Mol. Strut 2005, 744, 529-534. [CrossRef]

51. Mighri, N.; Mao, J.; Mighri, F.; Ajji, A.; Rouabhia, M. Chitosan-Coated Collagen Membranes Promote Chondrocyte Adhesion, Growth, and Interleukin-6 Secretion. Materials 2015, 8, 7673-7689. [CrossRef]

52. Chang, M.C.; Ikoma, T.; Kikuchi, M.; Tanaka, J. Preparation of a porous hydroxyapatite/collagen nanocomposite using glutaraldehyde as a crosslinkage agent. J. Mater. Sci. Lett. 2001, 20, 1199-1201. [CrossRef]

53. Chen, G.; Ushida, T.; Tateishi, T. Scaffold Design for Tissue Engineering. Macromol Biosci 2002, 2, 67-77. [CrossRef]

54. Wang, H.M.; Chou, Y.T.; Wen, Z.H.; Wang, Z.R.; Chen, C.H.; Ho, M.L. Novel biodegradable porous scaffold applied to skin regeneration. PLoS ONE 2013, 8, 118-126. [CrossRef]

55. Karageorgiou, V.; Kaplan, D. Porosity of 3D Biomaterial Scaffolds and Osteogenesis. Biomaterials 2005, 26, 5474-5491. [CrossRef]

56. Chen, G.; Kawazoe, N. 3.1-Preparation of Polymer Scaffolds by Ice Particulate Method for Tissue Engineering. In Biomaterials Nanoarchitectonics; Ebara, M., Ed.; William Andrew Publishing: New York, NY, USA, 2016; pp. 77-95.

57. Venkatesan, J.; Kim, S.; Wong, T.W. Chapter 9-Chitosan and Its Application as Tissue Engineering Scaffolds. In Nanotechnology Applications for Tissue Engineering; Thomas, S., Grohens, Y., Ninan, N., Eds.; William Andrew Publishing: New York, NY, USA, 2015; pp. 133-147.

58. Bartoš, M.; Suchý, T.; Foltán, R. Note on the Use of Different Approaches to Determine the Pore Sizes Of Tissue Engineering Scaffolds: What Do We Measure? BioMed Eng. OnLine 2018, 17, 110. [CrossRef]

59. Han, F.; Wang, J.; Ding, L.; Hu, Y.; Li, W.; Yuan, Z.; Guo, Q.; Zhu, C.; Yu, L.; Wang, H.; et al. Tissue Engineering and Regenerative Medicine: Achievements, Future, And Sustainability in Asia. Front. Bioeng. Biotechnol. 2020, 8, 83. [CrossRef]

60. Dzobo, K.; Thomford, N.E.; Senthebane, D.A.; Shipanga, H.; Rowe, A.; Dandara, C.; Pillay, M.; Motaung, K.S.C.M. Advances in Regenerative Medicine and Tissue Engineering: Innovation and Transformation of Medicine. Stem Cells Int. 2018, 2495848. [CrossRef]

61. Hebbar, R.S.; Isloor, A.M.; Ismail, A.F. Contact angle measurements in membrane characterization. Biomaterials 2017, 131, 167-178.

62. Wang, W.; Caetano, G.; Ambler, W.S.; Blaker, J.J.; Frade, M.A.; Mandal, P.; Diver, C.; Bártolo, P. Enhancing the Hydrophilicity and Cell Attachment of 3D Printed PCL/Graphene Scaffolds for Bone Tissue Engineering. Materials 2016, 9, 992. [CrossRef]

63. Remya, K.R.; Chandran, S.; Mani, S.; John, A.; Ramesh, P. Hybrid polycaprolactone/polyethylene oxide scaffolds with tunable fiber surface morphology, improved hydrophilicity and biodegradability for bone tissue engineering applications. J. Biomater. Sci. Polym. Ed. 2018, 29, 12. [CrossRef]

64. Rouabhia, M.; Mighri, N.; Mao, J.; Park, H.J.; Mighri, F.; Ajji, A.; Zhang, Z. Surface Treatment with Amino Acids of Porous Collagen-Based Scaffolds to Improve Cell Adhesion and Proliferation. Can. J. Chem. Eng. 2018, 39, 875-886. [CrossRef]

65. Zhang, D.; Wu, X.; Chen, J.; Lin, K. The development of collagen based composite scaffolds for bone regeneration. Bioact. Mater. 2018, 31, 129-138. [CrossRef] [PubMed]

66. Hu, Y.; Dan, W.; Xiong, S.; Kang, Y.; Dhinakar, A.; Wu, J.; Gu, Z. Development of Collagen/Polydopamine Complexed Matrix as Mechanically Enhanced and Highly Biocompatible Semi-Natural Tissue Engineering Scaffold. Acta Biomater. 2017, 47, 135-148. [CrossRef] [PubMed]

67. Liu, Z.; Tamaddon, M.; Gu, Y.; Yu, J.; Xu, N.; Gang, F.; Sun, X.; Liu, C. Cell Seeding Process Experiment and Simulation on Three-Dimensional Polyhedron and Cross-Link Design Scaffolds. Front. Bioeng. Biotechnol. 2020, 8, 104. [CrossRef] [PubMed]

68. Vigneswari, S.; Majid, M.I.A.; Amirul, A.A. Tailoring the Surface Architecture of Poly (3-hydroxybutyrate-co-4-hydroxybutyrate) Scaffolds. J. Appl. Polym. Sci. 2011, 124, 2777-2788. [CrossRef]

69. Lim, M.M.; Sultana, N. In Vitro Cytotoxicity and Antibacterial Activity of Silver-Coated Electrospun Polycaprolactone/Gelatine Nanofibrous Scaffolds. Biotech 2016, 6, 211. [CrossRef] 
70. Sandri, G.; Bonferoni, M.C.; D'Autilia, F.; Rossi, S.; Ferrari, F.; Grisoli, P.; Caramella, C. Wound Dressings Based on Silver Sulfadiazine Solid Lipid Nanoparticles for Tissue Repairing. Eur. J. Pharm. Biopharm. 2013, 84, 84-90. [CrossRef]

71. Siedenbiedel, F.; Tiller, J.C. Antimicrobial Polymers in Solution and On Surfaces: Overview and Functional Principles. Polymers 2012, 4, 46-71. [CrossRef]

72. Heo, D.N.; Yang, D.H.; Lee, J.B.; Bae, M.S.; Kim, J.H.; Moon, S.H.; Chun, H.J.; Kim, C.H.; Lim, H.N.; Kwon, I.K. Burn-Wound Healing Effect of Gelatin/Polyurethane Nanofiber Scaffold Containing Silver-Sulfadiazine. J. Biomed. Nanotechnol. 2013, 9, 511-515. [CrossRef]

73. Zhong, S.P.; Zhang, Y.Z.; Lim, C.T. Tissue Scaffolds for Skin Wound Healing and Dermal Reconstruction. Wiley Interdiscip. Rev. Nanomed. Nanobiotechnol. 2010, 2, 510-525. [CrossRef]

74. Kalantari, K.; Mostafavi, E.; Afifi, A.M.; Izadiyan, Z.; Jahangirian, H.; Rafiee-Moghaddam, R.; Webster, T.J. Wound Dressings Functionalized with Silver Nanoparticles: Promises and Pitfalls. Nanoscale 2020, 12, 2268-2291. [CrossRef]

75. Sripriya, R.; Kumar, M.S.; Ahmed, M.R.; Sehgal, P.K. Collagen Bilayer Dressing with Ciprofloxacin, an Effective System for Infected Wound Healing. J. Biomater. Sci. Polym. Ed. 2007, 18, 335-351. [CrossRef]

76. Timofeeva, L.; Kleshcheva, N. Antimicrobial polymers: Mechanism of action, factors of activity, and applications. Appl. Microbiol. 2011, 89, 475-492. [CrossRef] 